MATH DIDACTIC: JURNAL PENDIDIKAN MATEMATIKA

Volume 4 Nomor 1, Januari - April 2018, halaman 21 - 33

Tersedia Daring pada http://jurnal.stkipbjm.ac.id/index.php/math



\title{
PENGEMBANGAN MEDIA PEMBELAJARAN DART BOARD MATH BAGI SISWA KELAS VII SMP
}

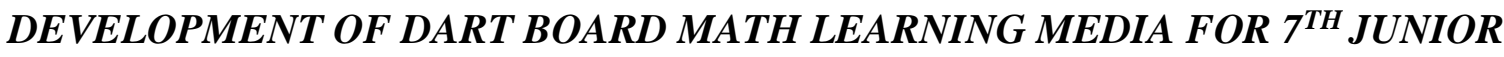 HIGHSCHOOL}

\author{
Desi Listiani, Erlina Prihatnani \\ Pendidikan Matematika UKSW Salatiga \\ 202014092@student.uksw.edu,erlina.prihatnani@gmail.com
}

\begin{abstract}
Abstrak: Rendahnya kemampuan siswa SMP terhadap materi aljabar, menjadi suatu tantangan untuk menciptakan inovasi pembelajaran. Penelitian ini bertujuan menciptakan media pembelajaran untuk membantu siswa dalam berlatih soal Aljabar. Model pengembangan yang digunakan pada penelitian ini adalah model ADDIE yang terdiri dari tahap Analyze, Design, Development, Implementation dan Evalutaion. Penelitian ini menghasilkan suatu produk media pembelajaran interaktif berupa Dart Board Math. Instrumen yang digunakan terdiri dari lembar validasi media, lembar kepraktisan, pretest, posttest, dan lembar pendapat siswa. Media ini telah diujicobakan terhadap 26 siswa kelas VII SMP N 2 Salatiga. Media Dart Board Math telah dinyatakan valid dari aspek materi dan aspek media pembelajaran dengan persentase berturut-turut $86,7 \%$ dan $89,7 \%$ keduanya termasuk kategori sangat baik. Hasil dari uji aspek kepraktisan mendapatkan persentase sebesar $84,1 \%$ yang masuk dalam kategori sangat baik. Uji pair t-test dengan taraf signifikan 5\% menghasilkan signifikan mendekati nol dengan rata rata posttest lebih tinggi daripada pre test. Berdasarkan ketiga uji tersebut, maka dapat disimpulkan media ini valid, praktis dan efektif.
\end{abstract}

Kata Kunci: Media Pembelajaran, Dart Board Math, Aljabar, model ADDIE

Abstract: The low ability of students in algebra is challenging for teachers to make innovation in the learning of algebra. This research aims to create learning media to help students in learning algebra. The model used for the development of this research is ADDIE, which consists 5 stages, such as Analyze, Design, Development Implementation, and Evaluation. This research produces a product of interactivelearning media called Dart Board Math. The instruments used consist of media validation sheet, praticality sheete, pre test, post test, and students' argument sheet. This media has been applied to 26 students in the 2nd Grade of Junior High School 2 Salatiga. The Dart Board Math has been classified as as valid from both material aspect and learning media aspect with precentage of $86,7 \%$ and $89,7 \%$ which are both classified as excellent. The precentage os praticality test result is $84,1 \%$ which is classified as excellent. Pair t-test of significance level of 5\% produce significance approaching zero with post test average higher than the pre test. Based on the three test that has been implemented, this meda of learing is classified to be valid, pratical and effective

Keywords : Learning Media, Dart Board Math, Algebra, ADDIE model

Cara sitasi: Listiani, D., \& Prihatnani, E. (2018). Pengembangan media pembelajaran dart board math bagi siswa kelas VII SMP. Math Didactic: Jurnal Pendidikan Matematika, 4(1), 21-33. 
Pelajaran matematika secara garis besar dibagi ke dalam 4 cabang yaitu aritmatika, aljabar, geometri, dan analisis (Bell, 1978, hal.27). Pembelajaran aljabar mulai diperkenalkan pada siswa di kelas VII SMP. Materi aljabar merupakan pengembangan dari aritmatika yang dipelajari siswa ketika duduk di bangku sekolah dasar. Namun data TIMSS 2011 menunjukkan bahwa kemampuan kognitif siswa Indonesia pada materi aljabar sangat rendah (Rosnawati, 2013, hal.2). Hasil pengkajian terhadap kesulitan yang dihadapi oleh guru matematika dan siswa SMP pada 5 provinsi yang diselenggarakan oleh PPPG Matematika tahun 2002 menunjukkan bahwa hampir semua provinsi menghadapi kendala berupa pemahaman yang rendah dari siswa tentang konsep-konsep yang terkait dengan operasi bentuk aljabar dan skill yang rendah dalam menyelesaikan operasi bentuk Aljabar. (Wardani, 2004, hal.1). Hal itu tentu sangat mengecewakan, mengingat aljabar merupakan cabang penting dari matematika. Jika siswa mengalami kesulitan dalam mempelajari aljabar di kelas VII, maka kemungkinan siswa juga akan mengalami kesulitan ketika mempelajari materi aljabar pada tingkat selanjutnya. Oleh karena itu, perlu strategi untuk meningkatkan kemampuan Aljabar siswa salah satunya dengan latihan soal.

Proses pemberian latihan soal hendaknya dikemas ke dalam kegiatan yang menarik agar dapat menantang siswa dan tidak menimbulkan kebosanan. Djamah \& Zain (1996, hal.109) mengungkapkan bahwa terkadang latihan yang dilaksanakan secara berulang-ulang merupakan hal yang monoton dan mudah membosankan. Oleh karena itu diperlukan suatu cara untuk menyajikan latihan soal menjadi suatu kegiatan yang menarik, salah satunya adalah dengan menggunakan media pembelajaran.

Setyorini (2012, hal.1) menyatakan bahwa dalam upaya untuk mencapai tujuan pembelajaran, guru dituntut untuk lebih kreatif dan inovatif dalam merancang dan menggunakan media pembelajaran. Senada dengan hal tersebut, Miller (2008, hal.5) menyatakan bahwa selama proses pembelajaran guru dituntut terampil dalam menyajikan kegiatan pembelajaran secara menarik sehingga proses belajar dapat menyenangkan. Permainan merupakan salah satu strategi yang dapat digunakan guru sebagai cara untuk mewujudkan hal tersebut. Oleh karena itu perlu dikembangkan media pembelajaran yang menarik, yang memasukkan unsur permainan serta mampu menumbuhkan semangat siswa untuk aktif, yang membuat siswa tidak merasa bosan dan jenuh dalam mengikuti pelajaran dan dapat menumbuhkan minat siswa dalam mengerjakan latihan soal. Media permainan diharapkan tidak hanya melatih aspek kognitif namun juga aspek psikomotorik maupun afektif. Hal itu dikarenakan dalam menjalankan suatu permainan dibutuhkan keterampilan dan juga melatih nilai-nilai afektif seperti rasa tanggung jawab, sportifitas, kejujuran dan rasa pantang menyerah.

Salah satu media pembelajaran berupa permainan yang mengakomodasi 3 aspek tersebut adalah media permainan Dart Board. Panahan (Dart) adalah suatu kegiatan menggunakan busur panah untuk menembakkan anak panah. Husni dkk (1990, hal.294) mendefinisikan panahan sebagai salah satu cabang olahraga yang menggunakan busur dan anak panah. Dalam permainan ini, setiap pemain harus mampu menembakkan anak panahnya mengenai 
sasaran yang telah ditentukan. Permainan ini dapat dimodifikasi sehingga dapat digunakan dalam pembelajaran matematika khususnya dalam upaya menciptakan kegiatan latihan soal sehingga lebih menyenangkan.

Terdapat beberapa penelitian yang telah memanfaatkan media Dart Board dalam pembelajaran, contohnya penelitian yang dilakukan Marfia (2016, hal.11) yang menggunakan media Dart Board pada mata pelajaran Akuntansi; dan Anggoro (2010, hal.4) yang juga menggunakan media Dart Board pada mata pelajaran IPS Sejarah. Tidak hanya menerapkan Dart Board, ada pula penelitian yang mengkhususkan tujuannya untuk mengembangkan media Dart Bard dalam pembelajaran, contohnya penelitian yang dilakukan oleh Muthakaromah (2015, hal.4) dan Annisa (2015, hal.3) yang berturut turut mengembangkan media untuk mata pelajaran Ilmu Pengetahuan Alam dan mata pelajaran Bahasa Prancis. Hasil penelitianpenelitian tersebut menyimpulkan bahwa media yang diciptakan berdampak positif terhadap minat dan hasil belajar siswa. Oleh karena itu penelitian ini akan mengembangkan media pembelajaran Dart Board namun untuk pembelajaran matematika yaitu materi aljabar.

Penelitian ini akan menciptakan suatu paket media Dart Board yang di dalamnya terdapat soal-soal latihan yang dapat digunakan siswa untuk melatih kemampuan mereka tentang materi aljabar. Tujuan dari penelitian ini adalah untuk menciptakan media Dart Board Matematika yang valid, praktis dan efektif yang dapat digunakan dalam pembelajaran. Diharapkan media ini dapat digunakan sebagai sarana untuk menyajikan latihan soal menjadi lebih menarik. Selain itu diharapkan pula media ini dapat mewujudkan pembelajaran yang aktif, kreatif, inovatif, efektif dan menyenangkan sehingga pembelajaran tidak membosankan, dan dapat menghasilkan hasil belajar siswa menjadi lebih baik.

\section{Metode Penelitian}

Penelitian ini merupakan penelitian pengembangan atau Research and Development (R\&D). Menurut Sujadi (2003, hal.164) penelitian pengembangan adalah suatu proses atau langkah-langkah untuk mengembangkan suatu produk baru, atau menyempurnakan produk yang telah ada, yang dapat dipertanggungjawabkan. Produk yang dihasilkan dalam penelitian ini berupa media pembelajaran matematika pada materi Aljabar untuk siswa kelas VII. Penelitian ini menggunakan metode pengembangan ADDIE. Model pengembangan ADDIE menurut Ibrahim (2011, hal.46) merupakan model desain pembelajaran yang berlandasan pada pendekatan sistem yang efektif dan efisien serta prosesnya yang bersifat interaktif yakni hasil evaluasi setiap fase dapat membawa pengembangan pembelajaran ke fase selanjutnya. Model ini terdiri atas lima fase auat tahap utama yaitu (A)nalysis, (D)esign, (D)evelopment, (I)mplementation dan $(E)$ valuation.

Pelaksanaan uji coba media dilaksanakan di Sekolah Menengah Pertama (SMP) Negeri 2 Salatiga. Penelitian ini melibatkan 3 ahli media pembelajaran (2 dosen dan 1 guru matematika) dan 3 ahli materi pembelajaran (2 guru matematika dan 1 dosen) serta melibatkan 1 guru matematika sebagai pihak yang akan menilai kepraktisan penggunaan media dan siswa kelas VII B yang sudah mempelajari materi Aljabar sebagai subyek yang mencoba penggunaan media ini. 
Data hasil validasi ahli media dan materi serta hasil uji kepraktisan berupa data kualitatif dan kuantitatif. Data kualitatif yang berupa kritik dan saran yang akan dijadikan sebagai pedoman untuk memperbaiki media pembelajaran yang dikembangkan. Adapun data kuantitatif yang diperoleh dari penilaian ahli materi dan ahli media akan dianalisis secara deskriptif. Kriteria skor penilaian ahli menggunakan skala dengan 4 interval yaitu

(1) Tidak baik, (2) Cukup Baik, (3) Baik, (4) Sangat Baik. Rumus yang digunakan dalam perhitungan untuk memperoleh persentase kelayakan adalah rumus (i). Setelah diperoleh persentase kelayakan, maka dilakukan kategorisasi berdasarkan ketentuan yang tercantum pada Tabel 1 .

$$
\mathbf{P}(\mathbf{s})=\frac{S}{N} \times 100 \%
$$

Keterangan :

$\mathrm{P}(\mathrm{s})=$ persentase sub variabel

$\mathrm{S}=$ jumlah skor tiap sub variabel

$\mathrm{N}=$ jumlah skor maksimum

Tabel 1. Kriteria Pengkategorian Hasil Penilaian Media Pembelajaran

\begin{tabular}{|c|c|c|}
\hline No. & Interval & Kriteria \\
\hline 1. & $80 \% \leq$ skor $\leq 100 \%$ & Sangat Baik \\
\hline 2. & $60 \% \leq$ skor $<80 \%$ & Baik \\
\hline 3. & $40 \% \leq$ skor $<60 \%$ & Cukup \\
\hline 4. & $20 \% \leq$ skor $<40 \%$ & Kurang \\
\hline 5. & $0 \% \leq$ skor $<20 \%$ & Tidak Baik \\
\hline
\end{tabular}

Hasil dari lembar pendapat siswa berupa data kualitatif akan dideskripsikan guna menggambarkan respon siswa setelah menggunakan media pembelajaran. Hasil dari pretest dan posttest digunakan sebagai data untuk menguji keefektifan. Uji yang dilakukan dengan uji pair t-test. Oleh karena itu, pada tahap awal akan dilakukan uji prasyarat yaitu uji normalitas. Pengolahan analisis data hasil belajar akan menggunakan SPPS versi 20 dengan taraf signifikan $5 \%$. Hipotesis penelitian ini adalah teruwujudnya media pembelajaran yang valid, praktis, dan efektif. Media dikatakan valid apabila hasil penilaian ahli materi dan media $\$ 80 \%$ (atau minimal masuk dalam kategori sangat baik). Media ini termasuk praktis digunakan apabila hasil penilaian kepraktisan $\geq 80 \%$ (atau masuk dalam kategori sangat baik) dan dikatakan efektif apabila terdapat perbedaan yang signifikan antara rata-rata nilai pretest dan posttest siswa dimana nilai posttest lebih tinggi.

\section{Hasil Penelitian dan Pembahasan}

\section{Hasil}

\section{Pengembangan} media pembelajaran matematika pada materi Aljabar, akan diujicobakan pada siswa kelas VII SMP Negeri 2 Salatiga. Berikut ini uraian dari proses pengembangan menurut tahapan ADDIE.

\section{a. ANALYSIS}

Tahap analisis pengembangan media ini melalui tahap analisis kebutuhan dan analisis kinerja. Hasil pada tahap analisis kebutuhan menyimpulkan bahwa diperlukannya media yang dapat menumbuhkan minat siswa dalam mengerjakan latihan soal yang dikemas secara menarik, yang dapat mewujudkan prinsip belajar sambil bermain dan dimungkinkan untuk penggunaannya dilaksanakan di dalam kelas. Media ini diharapkan dapat memberi kesempatan siswa untuk aktif bergerak. Salah satu caranya melalui media pembelajaran permainan. Media permainan diharapkan tidak hanya melatih aspek kognitif namun 
juga aspek psikomotorik maupun afektif. Hal itu dikarenakan dalam menjalankan suatu permainan dibutuhkan keterampilan dan juga melatih nilai-nilai afektif seperti rasa tanggung jawab, sportifitas, kejujuran dan rasa pantang menyerah.

Terdapat penelitian yang sudah mengembangkan media pembelajaran Dart Board diantaranya penelitian Muthakaromah (2015, hal.4) dalam pelajaran IPA. Peneliti memodifikasi papan dart dengan cara menambahkan beberapa gambar pada papan dart dan soal-soal yang harus dikerjakan dalam setiap angkanya. Namun jumlah soal tidak dipertimbangkan sehingga siswa berebut dalam pembagian kartu soal, siswa berebut dalam meminta kepada temannya. Selain itu, ada pula media Dart Board yang dikembangkan oleh Annisa (2015, hal.3) pembelajaran berbicara Bahasa Perancis. Kelebihan Dart board yang digunakan dalam penelitian ini telah dimodifikasi sedemikian rupa dan diberi tema-tema dalam bahasa Perancis tentang identitas diri, identitas orang lain, kegiatan yang digemari, kegiatan waktu luang, kegiatan selama akhir pekan, dan lainlain. Namun, terdapat kekurangan yaitu token permainannya berupa dart atau panah kecil. Hal tersebut kurang memperhatikan aspek keselamatan para siswa. Berdasarkan 2 media tersebut, penelitian ini juga akan mengembangkan media yang sama namun untuk mata pelajaran Matematika pada materi Aljabar. Media ini akan mengadopsi hal hal menarik dari 2 media sebelumnya dan mengembangkannya untuk memperbaiki kelemahan kelemahan yang ada.

Media yang diciptakan pada penelitian ini adalah media yang akan digunakan sebagai sarana latihan soal Aljabar. Oleh karena itu, diperlukan analisis terhadap materi ini. Materi Aljabar mencangkup kompetensi dasar yaitu (1) Menyelesaikan masalah yang berkaitan dengan operasi bentuk aljabar, (2) Menjelaskan dan melakukan operasi pada bentuk aljabar (penjumlahan, pengurangan, perkalian, dan pembagian, (3) Menyelesaikan masalah yang berkaitan dengan penyederhanaan bentuk aljabar, Menyelesaikan masalah nyata dalam bentuk aljabar yang diselesaikan dengan operasi bentuk aljabar.

\section{b. DESIGN}

Berdasarkan hasil analisis dan fakta yang ditemukan pada saat wawancara dengan guru, maka muncul ide untuk menciptakan media pembelajaran yang di dalamnya terdapat soal-soal latihan yang dapat digunakan siswa untuk melatih kemampuan mereka tentang materi aljabar. Media ini diadopsi dari olahraga cabang panahan. Olahraga panahan selama ini digunakan dengan busur panah maupun dengan melakukan lemparan pada papan dart board. Biasanya dimainkan oleh 2-3 orang pemain. Namun, media yang akan dikembangkan terbuat dari papan, bundar yang dilapisi oleh whiteboard berwarna dimana saat memainkannya memerlukan pistol mainan serta kartu soal yang berbeda beda warna sesuai dengan skornya.

\section{Seperti permainan Dart (Panahan)} pada umumnya, permainan pada media ini mewajibkan peserta memperoleh skor tertinggi. Media tersebut dibagi menjadi 3 bagian yaitu papan, pistol mainan dan kartu soal. Media ini nantinya akan digunakan di dalam kelas, maka perlunya design aturan permainan yang dapat digunakan di dalam kelas. Media ini dirancang agar dapat digunakan secara kelompok dengan memperhatikan jumlah siswa di dalam kelas. Jika satu kelas telah dibagi menjadi 4-5 
kelompok, maka setiap kelompok harus menentukan orang pertama hingga orang terakhir, hal ini dimaksudkan agar pemain bermain secara bergiliran sesuai urutan.

Dalam penggunaan permainan ini, diperlukan aturan agar permainan dapat berjalan dengan lancar, diantaranya proses penembakan ke sasaran yang ada di dalam papan. Sebelumnya, siswa di dalam kelas dibagi menjadi 4 kelompok, dengan jumlah anggota yang sama. Kemudian, siswa secara bergiliran memanah dart ke papan dart yang telah disediakan. Setelah peluru mengenai segmen di dalam dart board, pemain mengambil kartu soal sesuai dengan perolehan skor dan warna yang didapat. Pengerjaan soal dilakukan secara diskusi kelompok agar semua anggota kelompok terlibat aktif dan dapat memahami jawaban yang sudah didiskusikan. Setelah siswa berdiskusi dengan kelompoknya, siswa yang mendapat giliran untuk memanah, wajib menuliskan jawaban ke dalam kertas jawaban yang telah disediakan. Begitupula dengan pemain selanjutnya sampai berakhirnya waktu bermain. Kelompok yang memenagkan permainan ini adalah kelompok yang mempunyai skor tertinggi. Berdasarkan uraian tersebut, tampak bahwa permainan dengan media ini menuntut adanya tanggung jawab individu, dimana setelah siswa melakukan diskusi, siswa yang mendapat giliran memanah harus menuliskan jawaban soal (hasil diskusi) secara mandiri pada 1 lembar jawab.

Dart board pada umumnya, terdiri atas 20 segmen, namun dari warna asalnya yang hanya berwarna hitam dan putih, Dart board Math ini mengganti warna warna tersebut dengan warna yang menarik dan sesuai dengan tingkat gradasi warnya. Warna yang dipilih adalah kuning, merah, biru, hitam dan hijau. Media ini menuntut adanya proses pengerjaan soal di setiap segmen yang berwarna. Skor permainan ini semakin dalam akan semakin besar, yaitu skor 10 - 40 . Dimana semakin besar skor, maka tingkat kesulitan soal akan semakin sulit. Di dalam Dart board ini soal akan diacak sesuai dengan urutan indikator, hal tersebut bertujuan agar siswa tidak bisa menebak soal apa yang akan mereka dapatkan. Di bagian terluar, terdapat soal indikator 1 sampai dengan 7 yang diletakkan berturut turut mulai dari warna kuning skor 10 untuk indikator 1 dan searah jarum jam untuk indikator 2 dan seterusnya. Demikian pula untuk skor bagian dalam, indikator juga tersebar secara bergilir searah dengan jarum jam dimulai dari warna orange dengan skor 20. Skor 40 memiliki soal yang mencampurkan indikator 1-7, maka dalam skor 40 soal yang dikerjakanpun semakin sulit. Bahan pembuatan dari Dart Board Math adalah papan triplek, yang dilapisi oleh white board yang diluarnya ditempel stiker berdesain menarik. Desain Dart Board dapat dilhat pada Gambar 1 berikut.



Gambar 1 : Desain Dart Board

Berbeda dengan permainan dart board pada umumnya yang menggunakan dart yaitu alat lempar berbentuk runcing, Media 
yang dikembangkan ini menggantinya dengan menggunakan pistol mainan. Pemilihan pistol mainan dipertimbangkan mengingat para pemain adalah siswa kelas VII, maka dipilihlah komponen permainan yang aman digunakan untuk bermain. Selain itu, penggunaan pistol mainan juga melatih ketangkasan siswa untuk menembak menuju sasaran skor yang sudah disediakan. Pistol mainan juga menempel dengan Dart Board yang terbuat dari white board. Gambar pistol yang digunakan dapat dilihat pada Gambar 2 berikut.

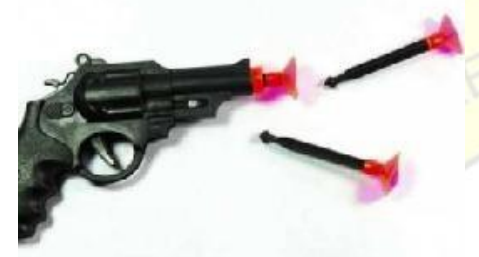

\section{Gambar 2 : Dart media Dart Board}

Desain kartu soal atau lembar soal disesuaikan dengan warna yang ada pada papan dart board yang telah dibuat. Setiap kartu memiliki skor yang berada di bagian kiri atas. Selain itu terdapat lingkaran di bawah kartu soal yang diatasnya terdapat angka yang menunjukan indikator. Hal ini disesuaikan untuk mempermudah guru untuk mencari dalam kunci jawaban agar mudah ditemukan. Ukuran sebuah kartu soal ialah $9 \times 5 \mathrm{~cm}$, hal ini bertujuan agar soal mudah dan jelas dibaca. Media Dart Board Math agar lebih efektif dalam keawetan maka dipilihlah kertas yang dapat bertahan lama dengan pemilihan kertas ivory 360. Desain kartu dibedakan menjadi 2, yaitu desain kartu dengan skor 1030, dan desain kartu soal dengan skor 40. Hal tersebut mengingat skor 40 mempunyai soal kompleks (campuran indikator 1-7). Desain kartu tersebut dapat dilihat pada Gambar 3 berikut.

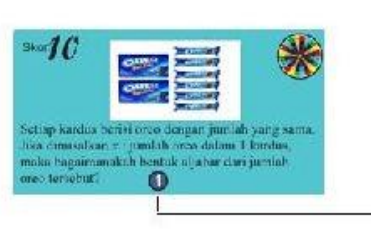

1 Keterangan :

1. Letak skor

2 2. Warna kartu sesuai

dengan Dart Board

3. Indikator soal

Gambar 3. Desain Kartu

Desain media ini juga memperhatikan aspek kepraktisan dalam penyimpanan, maka dalam penelitian ini juga mendesain pengemasan media dalam bentuk sebuah box. Pengemasan media menggunakan bahan yang awet dan dirancang sedemikian rupa sehingga praktis untuk dibawa. Bahan yang dipilih yaitu berbahan dasar kayu. Berat box tersebut kurang lebih 7,5 kg, karena di dalamnya terdapat komponen-komponen permainan yang lengkap. Setiap sisi box ini ditempel stiker yang sesuai dengan gambar desain media. Pengemasan media ini dapat dilihat pada gambar 4 .

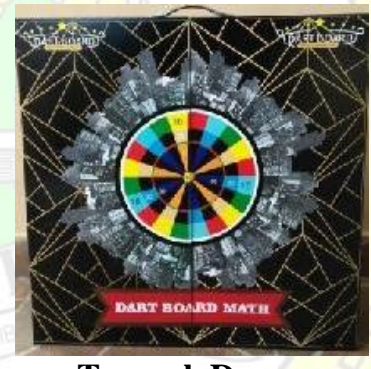

Tampak Depan

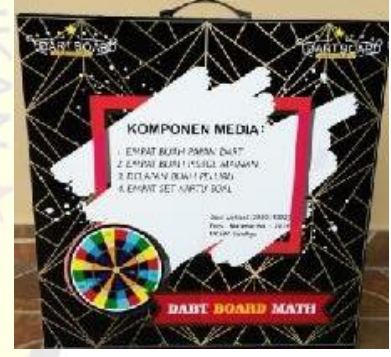

Tampak Belakang

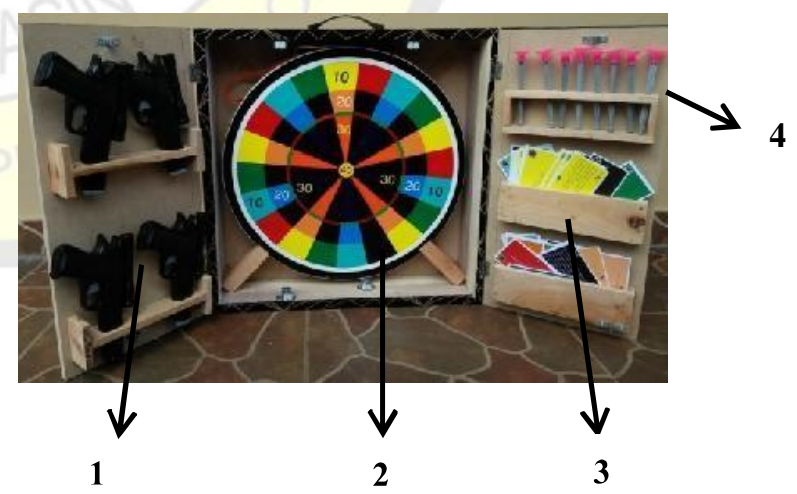

Gambar 4 : Pengemasan Media Dart Board Math
Keterangan :
1. Tempat Pistol Mainan
2. Tempat Dart Board
3. Tempat Kartu Soal
4. Tempat Peluru Pistol Mainan 


\section{c. DEVELOPMENT}

\section{Pada tahap Development} (pengembangan) media ini, diujikan kepada beberapa validator ahli materi dan ahli media. Validator untuk Ahli Materi ialah 2 guru matematika SMP yaitu Ibu Dra. Rikah di SMP N 10 Salatiga dan Ibu Haryati. S.Pd di SMP N 2 Salatiga dan 1 dosen pendidikan matematika UKSW yaitu Bp. Tri Nova Hasti Yunianta M.Pd. Hasil penilaian ini dapat dilihat pada Tabel 2.

Tabel 2. Validasi Ahli Materi

\begin{tabular}{ccc}
\hline Aspek Penilaian & Persentase (\%) & Kategori \\
\hline Aspek Materi & $81,9 \%$ & Sangat Baik \\
Aspek Konstruksi & $91,6 \%$ & Sangat Baik \\
\hline Rata-rata & $\mathbf{8 6 , 7 \%}$ & Sangat Baik \\
\hline
\end{tabular}

Pada tahap validasi Ahli Media, dilakukan oleh 2 dosen yaitu Tri Nova Hasti Yunianta M.Pd, Danang Setiyadi dan 1 guru matematika SMP di SMP N 2 Salatiga yaitu Haryati S.Pd. Ahli media memberikan saran dan masukan terlihat pada Tabel 3.

Tabel 3. Validasi Ahli Media

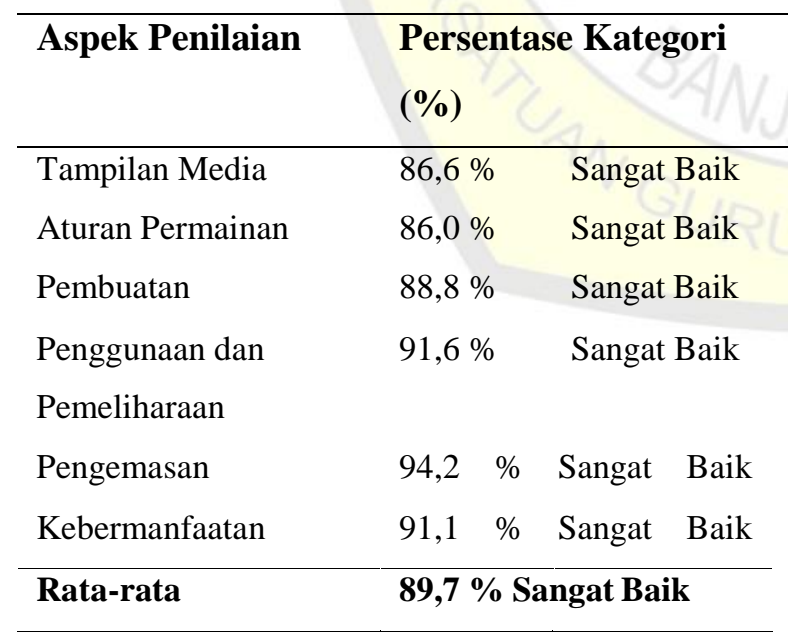

\section{d. IMPLEMENTATION}

Media ini diujicobakan pada 1 kelas di SMP Negeri 2 Salatiga selama 4 kali pertemuan. Pertemuan pertama untuk melakukan pretest untuk mengetahui kemampuan awal siswa. Pretest diberikan kepada siswa dikarenakan siswa telah mendapat materi Aljabar. Pertemuan kedua dan ketiga untuk menggunakan media dan pertemuan keempat untuk melakukan post test. Kendala pada saat penggunaan media adalah pengaturan persiapan penggunaan lama, karena bantuan para siswa. Adapun dibutuhkannya waktu untuk penataan kelas yang diperlukan agar proses dalam permainan dapat berjalan dengan baik.

Rekapitulasi hasil lembar kepraktisan, uji kepraktisan ini dilakukan oleh 1 guru matematika yaitu Ibu Haryati, S.Pd. Validator memberikan saran dan masukkan seperti pada Tabel 4.

Tabel 4. Rekapitulasi Hasil Validasi Uji Kepraktisan

\begin{tabular}{lll}
\hline Aspek Penilaian & Persentase & Kategori \\
\hline Pembuatan & $83,3 \%$ & Sangat Baik \\
Persiapan & $83,3 \%$ & Sangat Baik \\
Penggunaan & & \\
Penggunaan & $85,7 \%$ & Sangat Baik \\
\hline Rata-rata & $\mathbf{8 4 , 1} \%$ & Sangat Baik \\
\hline
\end{tabular}

\section{e. EVALUATION}

Media ini diujicobakan kepada siswa kelas VII yang sudah mempelajari materi Aljabar. Sebelum menggunakan media ini, siswa diberikan kesempatan untuk mengerjakan soal pre test yang telah disediakan. Tes ini terdiri dari 6 soal uraian media. Namun, hal tersebut tidak berlangsung 
yang meliputi 4 Kompetensi Dasar dari materi Aljabar. Selanjutnya siswa diberi kesempatan untuk menggunakan media. Pada tahap akhir, siswa kembali diberi kesempatan untuk tes dengan jumlah soal dan bentuk soal yang sama. Soal pre test dan post test memiliki kesamaan dalam tingkat keragaman dan kesulitan soal. Adapun hasil pre-test dan post test dapat dilihat pada Tabel 5.

Tabel 5. Hasil Pretest dan Posttest

\begin{tabular}{cccccc}
\hline & N & Min & Max & Mean & Std. Dev \\
\hline Pretest & 26 & 37,00 & 82,00 & 63,00 & 10,51 \\
Posttest & 26 & 55,00 & 96,00 & 81,03 & 09,00 \\
\hline $\begin{array}{c}\text { Valid N } \\
\text { (listwise) }\end{array}$ & 26 & & & & \\
\hline
\end{tabular}

Berdasarkan Tabel 4 dapat dilihat bahwa nilai maksimal dan minimum post test lebih tinggi dari pada pre test. Begitu pun
SPSS dengan tahap awal berupa Uji Normalitas data terlebih dahulu.

Tabel 6. Uji Normalitas

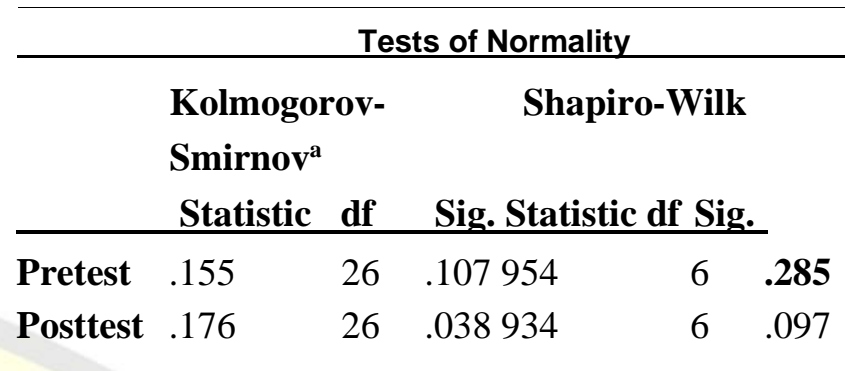

Pengambilan data siswa berjumlah 26 orang (kurang dari 30), maka uji normalitas yang digunakan adalah Shapiro-Wilk. Nilai signifikan dari nilai pre test sebesar 0,285 dan nilai post test sebesar 0,097 , keduanya lebih dari 0,05 . Hal tersebut menunjukkan bahwa kedua data berdistribusi normal. Oleh karena itu digunakan uji parametrik dengan uji pair t-test. Hasil uji ini dapat dilihat pada Tabel 7.

Tabel 7. Uji Paired Sample T-Test

\begin{tabular}{|c|c|c|c|c|c|c|c|c|}
\hline \multicolumn{9}{|c|}{ Paired Samples Test } \\
\hline & \multicolumn{5}{|c|}{ Paired Differences } & \multirow[b]{3}{*}{$\mathbf{t}$} & \multirow[b]{3}{*}{ df } & \multirow[b]{3}{*}{ Sig. (2-tailed) } \\
\hline & \multirow[b]{2}{*}{ Mean } & \multirow{2}{*}{$\begin{array}{l}\text { Std. } \\
\text { Dev }\end{array}$} & \multirow{2}{*}{$\begin{array}{l}\text { Std. } \\
\text { Error } \\
\text { Mean }\end{array}$} & \multicolumn{2}{|c|}{$\begin{array}{l}\text { 95\% Confidence Interval of } \\
\text { the Difference }\end{array}$} & & & \\
\hline & & & & Lower & Upper & & & \\
\hline $\begin{array}{r}\text { Pair } 1 \text { pretest - } \\
\text { posttest }\end{array}$ & $-18,038$ & 4,485 &, 880 & $-19,850$ & $-16,227$ & $-20,506$ & 5 & ,000 \\
\hline
\end{tabular}

juga hasil rata-rata kelas pada pre test mengalami peningkatan pada post test. Tidak hanya itu, penggunaan media juga memperkecil kesenjangan perbedaan kemampuan aljabar di kelas tersebut. Serta terdapat peningkatan siswa dalam kategori sedang yang meningkat pada siswa dalam kategori sangat tinggi.

Guna mengetahui apakah media efektif untuk digunakan untuk sarana latihan soal materi Aljabar kelas VII SMP, maka diperlukan uji inferensial. Hasil dari Hasil dari pretest dan postest diolah menggunakan 
Tabel 8. Rekapitulasi Pendapat Siswa terhadap Media

\begin{tabular}{|c|c|c|c|c|c|}
\hline \multirow[t]{2}{*}{ Indikator } & \multirow[b]{2}{*}{ SK } & \multicolumn{4}{|c|}{ Keterangan dalam \% } \\
\hline & & $\mathbf{K}$ & $\mathbf{C}$ & $\mathbf{S}$ & SS \\
\hline Aturan jelas & 0 & 0 & 19,23 & 53,84 & 26,92 \\
\hline $\begin{array}{l}\text { Media mudah } \\
\text { digunakan }\end{array}$ & 0 & 7,69 & 23,07 & 46,15 & 23,07 \\
\hline $\begin{array}{l}\text { Media asyik } \\
\text { dimainkan }\end{array}$ & 0 & 0 & 7,69 & 42,30 & 50,00 \\
\hline $\begin{array}{l}\text { Media dapat } \\
\text { digunakan } \\
\text { untuk belajar } \\
\text { sambil } \\
\text { bermain }\end{array}$ & 0 & 0 & 11,53 & 30,76 & 57,69 \\
\hline $\begin{array}{l}\text { Media } \\
\text { bermanfaat }\end{array}$ & 0 & 3,84 & 19,23 & 34,61 & 42,30 \\
\hline
\end{tabular}

Keterangan :

$\begin{array}{lll}\text { SK } & \text { : Sangat Kurang } & \text { S : Setuju } \\ \text { K } & \text { : Kurang } & \text { SS : Sangat Setuju } \\ \text { C } & \text { : Cukup } & \end{array}$

\section{Pembahasan}

Sebelum penyusunan media, dilakukan tahap pertama yaitu tahap analisis, dimana pada tahap ini akan menganalisis beberapa hal yaitu analisis kinerja dan analisis kebutuhan. Pada tahap analisis kinerja akan menganalisis kurikulum yang ada sesuai dengan kebutuhan yang akan digunakan dalam media Dart Board Math serta pada tahap analisis kebutuhan akan menganalisis kurikulum yang berlaku sesuai dengan prinsip $\mathrm{SK}, \mathrm{KD}$, dan teori belajar siswa serta materi Aljabar. Hal tersebut sesuai dengan pendapat Mulyatiningsih (2011, hal.84), pada tahap Analisis kegiatan utama adalah menganalisis perlunya pengembangan model/metode pembelajaran baru dan menganalisis kelayakan dan syarat-syarat pengembangan model/metode pembelajaran baru. Pengembangan metode pembelajaran baru diawali oleh adanya masalah dalam model/metode pembelajaran yang sudah diterapkan. Hal inilah yang menyebabkan adanya penciptaan media yang sesuai dengan kebutuhan maupun sesuai dengan kinerja.

Hasil rekapitulasi validasi ahli materi pada Tabel 2 dan validasi ahli media pada Tabel 3 telah menunjukkan persentase penilaian berturut-turut $86,7 \%$ dan $89,7 \%$ yang keduanya termasuk kategori Sangat Baik. Hal ini telah mencapai indikator kevalidan, sehingga dapat disimpulkan bahwa media Dart Board Math valid untuk digunakan.

Pada Tabel 2 dapat dilihat bahwa bagian aspek materi dan aspek konstruksi, keduanya masuk dalam kategori sangat baik. Ketiga validator materi menilai bahwa soal soal yang ada pada kartu soal telah beragam dan mecakup indikator-indikator dalam materi Aljabar.

Berdasarkan hasil pada Tabel 3, tampak bahwa keenam aspek penilaian media tersebut masuk kategori sangat baik. Ketiga validator memberi penilaian yang sama yaitu pada aspek tampilan media berupa nama media, desain Dart Board, dan ukuran kartu soal. Media memperhatikan tampilan yang mencerminkan materi Aljabar. Pada aspek aturan permainan validator menilai sesuai. Pada aspek pembuatan media berupa aturan permainan media terjangkau dan pemilihan bahan, validator menilai telah sesuai. Pada aspek penggunaan dan pemeliharaan berupa media awet untuk digunakan, validator menilai telah sesuai. Hal ini sesuai dengan salah satu prinsisp pemilihan media pembelajaran menurut Arsyad (2006, hal.75) Media sebaiknya praktis, luwes dan bertahan. Pada aspek pengemasan berupa tempat penyimpanan media. Pada aspek kebermanfaatan media memiliki prinsip belajar dan bermain, media menumbuhkan unsur menyenangkan, dan media membuat siswa aktif validator menilai semua aspek 
tersebut telah sesuai. Hasil validasi ahli media dengan persentase $89,7 \%$ maka dapat disimpulkan bahwa media dinyatakan valid dari aspek media matematika.

Hasil uji kepraktisan didapatkan pada aspek pembuatan, aspek persiapan penggunaan dan aspek penggunaan yang dinilai sangat baik oleh validator. Meskipun demikian, terdapat catatan dalam pemasangan media pada awal penggunaan, yaitu perlunya survei ketinggian dan posisi pemasangan media sebelum digunakan. Kemudian dari aspek penggunaan yang dinilai sangat baik oleh satu validator yaitu media menjadi sarana efektif untuk memberikan latihan soal. Pada hasil validasi uji kepraktisan oleh validator maka dapat disimpulkan bahwa media termasuk dalam kategori sangat baik dengan persentase $84,1 \%$. Berdasarkan saran dan masukan tersebut maka media ini dapat dikatakan praktis.

Terlihat pada Tabel 7, nilai signifikasi dari uji tersebut yaitu .000 , artinya nilai signifikasi mendekati nol yang kurang dari 0.005 sehingga dapat disimpulkan bahwa terdapat perbedaan yang signifikan antara nilai pretest dan posttest. Selisih nilai pretest dan posttest yaitu $-18,038$ (negatif), hal ini menunjukan bahwa nilai posttest lebih tinggi dibandingkan nilai pretest. Hal tersebut sesuai dengan Teori Behaviorisme yang menjelaskan bahwa perilaku sepenuhnya merupakan hasil dari kegiatan belajar. Sanyata dalam Rusuli (2014, hal.41) konsep behaviorisme memandang bahwa perilaku individu merupakan hasil belajar yang dapat diubah dengan memanipulasi dan mengkreasikan kondisi-kondisi belajar dan didukung dengan berbagai penguatan (reinforcement) untuk mempertahankan perilaku atau hasil belajar yang dikehendaki. Maka dapat disimpulkan media ini efektif untuk digunakan sebagai sarana latihan soal Aljabar pada jenjang SMP. Interpretasi pendapat siswa terhadap media, tidak seorang siswa berpendapat bahwa aturan media tidak jelas, media tidak asyik digunakan, dan media tidak dapat digunakan untuk belajar sambil bermain. Terdapat $7,69 \%$ siswa kurang setuju bahwa media mudah digunakan. Hal itu dikarenakan siswa kurang ahli dalam menggunakan pistol mainan yang disediakan. Terdapat pula 3,84\% siswa yang berpendapat kurang pada media bermanfaat untuk digunakan. Namun, sebagian besar siswa berpendapat setuju pada aturan media jelas dan media mudah digunakan yang berturut turut mendapatkan persentase sebesar $53,84 \%$ dan $46,15 \%$. Serta sebagian besar siswa berpendapat sangat setuju pada media asyik digunakan sebesar $50,00 \%$, media dapat digunakan untuk belajar sambil bermain sebesar $57,69 \%$ dan media bermanfaat sebesar $42,30 \%$

\section{Simpulan dan Saran}

\section{Simpulan}

Media ini telah dinyatakan valid dari aspek materi dan aspek media pembelajaran dengan persentase berturut-turut $86,7 \%$ dan $89,7 \%$ keduanya termasuk kategori sangat baik. Media ini diujicobakan kepada siswa kelas VII B SMP N 2 Salatiga dan menghasilkan indeks kepraktisan penggunaan sebesar $84,1 \%$ yang termasuk kategori sangat praktis. Uji pair t-test dengan taraf signifikan $5 \%$, menghasilkan signifikan mendekati nol yang kurang dari 0,05 dengan rata rata posttest lebih tinggi daripada pretest. Berdasarkan hasi ketiga uji tersebut tampak bahwa media Dart Board Math valid, praktis dan efektif untuk digunakan sebagai media 
pembelajaran yang dapat digunakan sebagai sarana latihan soal materi Aljabar pada jenjang SMP.

\section{Saran}

Penelitian ini menyarankan bagi guru untuk menggunakan media Dart Board Math sebagai sarana latihan soal Aljabar pada pembelajaran matematika. Selain itu diharapkan media ini dapat menginspirasi guru maupun peneliti selanjutnya untuk mengembangkan sarana latihan soal yang menarik untuk digunakan.

\section{Daftar Pustaka}

Anggoro, R. N. (2010). Meningkatkan Motivasi Belajar Siswa pada Pelajaran IPS Terpadu (Sejarah) melalui Pemanfaatan Media Dart Board dengan Teknik Permainan di Kelas VII H SMP Negeri 2 Malang Tahun Ajaran 2009/ 2010.Skripsi. Malang: Jurusan Sejarah FS Universitas Negeri Malang.

Annisa, Nurul Zahrah (2010) Penggunaan

Teknik Permainan Darts Dengan Media

Dart Board Dalam Pembelajaran

Berbicara Bahasa Perancis. S1 thesis, Universitas Pendidikan Indonesia.

Arsyad, Azhar, (2006). Media Pembelajaran. Jakarta: PT. Raja Grafindo Persada

Bell, F.H.. (1978). Teching Learning Mathematics: In Secondary Shooles. Iowa: Wn. C. Brown Company Publishers.

Djamarah, S.B., \& Zain, A. (1996). Strategi

Belajar Mengajar. Jakarta: Rineka Cipta.

Husni, A., Hakim, L., Gayo, M. AR. (1990).

Buku Pintar Olahraga. Jakarta : C.V. Mawar Gempita
Miller, C. S. (2008). Meaningful work over the life course. (Dissertation, The faculty of fielding graduate university

Mukhtaromah, Annisa Romadhani Luthfie (2015) "Keefektifan Model Pembelajaran Kooperatif Student Team Achievement Division (STAD) Berbantuan Media Papan Dart Materi Kalor dan Perpindahannya Terhadap Hasil Belajar Siswa" (Skripsi). Semarang : Universitas Negeri Semarang.

Mulyatiningsih, Endang. (2011). Metode Penelitian Terapan Bidang Pendidikan. Yogyakarta: Alfabeta

Ibrahim, Reyzal. (2011). Model Pengembangan ADDIE. Diakses tanggal 2 Maret 2017 WIB dari http://jurnalpdf.info/pdf/modelpengembangan-addie.html

Rosnawati. (2013). Kemampuan Penalaran Matematika Siswa SMP Indonesia Pada TIMSS 2011. Prosiding Seminar Nasional Penelitian, Pendidikan dan Penerapan MIPA, yang diselenggarakan oleh Fakultas MIPA, UNY, tanggal 18 Mei 2013. Yogyakarta: Universitas Negeri Yogyakarta.

Rusuli, Izzatur (2014). Refleksi Teori Belajar Behavioristik Dalam Prespektif Islam. Jurnal Pencerahan Volume 8 Nomor 1, Juli-Desember 2014

Setyorini, Indah (2010). Penggunaan Media Permainan Kartu Kuartet Pada Mata Pelajaran IPS untuk Peningkatan Hasil Belajar Siswa di Sekolah Dasar. JPGSD Volume 01 Nomor 02 Tahun 2013, 0-216

Sujadi, (2002). Metodologi Penelitian Pendidikan. Jakarta: Rineka cipta

Susanti, Marfia Pipin. (2016). Implementasi Model Pembelajaran Kooperatif Tipe Teames Games Tournament (TGT) Dengan Media Dart Board Untuk Meningkatkan Motivasi Belajar 
Akutansi Siswa Kelas XI Akutansi 4 SMK YPKK 2 Sleman Tahun Ajaran 2015/2016. Skripsi. Yogyakarta: Fakultas Ekonomi Universitas Negeri Yogyakarta

Wardhani, Sri. (2004) Permasalahan Kontekstual Mengenalkan Bentuk Aljabar Di SMP. Yogyakarta: Paket Pembinaan Penalaran 